\title{
Theory of Critical Legal Studies and the General Election and Presidential Election 2019 (Case Study: Critical Legal Studies of IAIN Ponorogo Students)
}

\author{
Dewi Iriani $^{1}$, Martha Eri Safira ${ }^{2}$, and Arief Budiono ${ }^{3 *}$ iD \\ ${ }^{1}$ Institut Agama Islam Negeri Ponorogo, Ponorogo, Indonesia \\ ${ }^{2}$ Institut Agama Islam Negeri Ponorogo, Ponorogo, Indonesia \\ ${ }^{3}$ Universitas Muhammadiyah Surakarta, Surakarta, Indonesia \\ *Corresponding author: areevahims@gmail.com
}

\section{Abstract}

In 2019, presidential and legislative candidates were elected simultaneously on April 17, 2019. Likewise, students are given the right to choose the mind and critical spirit of problem formulations 1) What are the obstacles in implementing the 2019 simultaneous election according to Fakultas Syariah student Iain Ponorogo? 2) What are the factors of Fakultas Syariah student Iain Ponorogo so that they are interested in choosing the Presidential and Vice-Presidential candidate pair No. 1 and the candidate pair for President and Vice President No. 2? 3) What are the factors that make Falkutas Syariah student Iain Ponorogo in choosing a legislative candidate? This research is a qualitative research with the type of field research. Research results 1) The implementation of the 2019 general election students do not understand because the KPU does not provide socialization, unknown candidates, election violations, many KPPS officers have died which has been shown, the factor of the figure of the presidential and vice-presidential candidates is also their consideration in giving their voting rights, choosing candidates because they follow their parents. 3) The student factor chooses a candidate from if they know the candidate choosing from the vision and mission of the candidate, but if the candidate is not known to choose from a political party, he chooses because he gets basic food and money.

Keywords: 2019 Election, thoughts, presidential candidates, legislative candidates

History:
Received: February $1^{\text {st }} 2021$
Accepted: February $20^{\text {th }} 2021$
Published: February $26^{\text {th }} 2021$

\section{INTRODUCTION}

In its development, Critical Legal Studies is a school of legal formalism or legal positivism. In other words, Critical Legal Studies is part of legal realism, Marxist legal theory, feminist legal theory, or postmodern legal theory. The differences in Critical Legal Studies in Canada are more dominated by the Marxist philosophy of law. While in the United States by postmodernism.

Critical Legal Studies Thought by Donny Danardono, in the journal Kisi Hukum Scientific Journal of Law. He thinks that CLS politics is a movement of legal pluralism, because the norms of traditional rules are not categorized as "state law" for solving non-legal cases. Interpretation of the meaning of non-law when applying law In Indonesia, namely the "Mengingat" part of a legal rule (Law, Presidential Decree, Ministerial decree, Governemnet Regulation, or Local Regulation), the Constitution is a higher hierarchy of regulations (Danardono 2019). 
Students must think critically about the sharing of issues rife in Indonesia. Therefore, students have been trained since the first semester, in the lecture it takes place to think critically by analyzing cases through arguments and analysis that students convey in class. Sharia faculty students are not only taught about Islamic law but also taught other positive legal materials, this is what distinguishes the sharia faculty from other faculties at IAIN Ponorogo. Where sharia faculty students build a critical mind and spirit, students are not only smart in class but also have to be sensitive to current news that are being discussed by people.

Academic data from IAIN Ponorogo, the total number of active students is 7280 students in 2019, and 1429 are Sharia faculty students at IAIN Ponorogo. From this data, there were 1429 students from the Sharia Faculty of IAIN Ponorogo who participated in this 2019 democracy party. Students as agents of change must take a stand and move quickly in responding to their environmental conditions and not abstain from voting when a democratic party is held. Apart from having the right to get a proper education, students are also entitled to voice their opinions, especially in the 2019 elections.

Election polarization is not only for the implementation of elections, but at the election organizers it creates problems. As happened in Hastinapura Regency, the violation of the code of ethics by the KPU commissioner Hastinapura who allegedly violated the verification rules of election participants. The lack of transparency in the election by PKPI officials as election participants, who lobbied politics to pass election verification, can be said to have violated ethics.

Various lobbying and political maneuvers were carried out by PKPI officials Hastinapura, in the verification stage of election participants so that they could pass. The Hastinapura KPU does not impose sanctions on political parties that engage in political lobbying, due to the weakness of election laws and regulations from the KPU. Another case in the KPU Sidoarjo is that the verification and responsibility of the election organizers are inaccurate. The verification officer did not meet a sample of political party members in the field. The final conclusion of election verification does not reflect the integrity of the election organizers (Widyo 2017).

2019 is a very special year for Indonesia, where a five-year democratic party is held, namely the election of legislative and presidential candidates. And what is even more special is that the democratic party in the form of this election is held simultaneously, namely the election of legislative and presidential candidates simultaneously on April $17^{\text {th }}, 2019$. Here, accuracy, maturity and intelligence are needed for the community in choosing who is a legislative candidate who is indeed pro to the people of $2^{\text {nd }}$ Level, namely the Regency and or Municipal, then the $1^{\text {st }}$ level at the province and at the central level, as well as at the same time choosing the right presidential candidate to lead and bring this country to be better and more prosperous for its people.

Students as agents of change in determining their choices also need critical and scientific thinking on what underlies themselves in choosing a legislative candidate from party A or presidential candidate pair number 1 or number 2 . Based on data from the KPU from 5 years to 5 years there is a tendency of voters that there are increasing numbers of people under the age of 25, especially student and university voters. Even this year's election is $38 \%$ dominated by students and students from the total voting rights and elected by Indonesian citizens. If a comparison is made, then $28 \%$ of the votes come from students or a quarter of more voters come from students, that is if they want to use their voting rights or not abstain. Therefore, this study is interested in examining the implementation of the 2019 election from the critical thinking of students, especially students of Sharia Faculty IAIN Ponorogo. What is the rationale for and assessment of certain legislative and presidential candidates, and what are their bases for selecting the legislative and presidential candidates. 
Referring to the background description of the above problems, the problems that can be formulated are deigned with the main descriptions concerning the Critical Legal Studies: Critical Thought of IAIN Ponorogo Student's Against the 2019 Election with three legal issues:

1. What are the obstacles in the implementation of the 2019 simultaneous election according to Sharia Faculty student IAIN Ponorogo?

2. What were the factors of Sharia Faculty student Iain Ponorogo so that they were interested in choosing Presiden and Vice-Presiden candidate No. 1 and Presiden and Vice-Presiden candidate No. 2?

3. What are the factors that make Sharia Faculty students Iain Ponorogo in choosing a legislative candidate?

\section{MATERIALS AND METHODS}

This research is a quantitative research with the type research is field research, which examines the knowledge of Sharia Faculty students and their thoughts on the 2019 general election, the General Election Commission of Ponorogo Regency and Election Supervisory Committee of Ponorogo Regency. The approach of research is a normative juridical approach and sociological theory. Research analysis using deductive exploratory method to the problems faced in this study.

\section{RESULTS AND DISCUSSION Concept of Critical Legal Studies}

Hubert Rottleuthner devide the characteristics of critical theory developed by Adorno and Horkheimer, namely: First, critical theory fosters a critical attitude to interpret ideas to be critical. Second, critical theory is based on historical thinking. The origin of humans from the connected part of the natural environment in the world. Third, in critical theory develops a comprehensive theory of understanding the social conditions of society. This theory comes from the Neo-Marxian theory, the teaching of which is a society that adapts to other societies (Wottleuthner 2010).

Donny Gahral Adian criticized the Frankfurt Madzhab, it must fulfill three conditions, namely: (a) criticizing the existing reality; (b) criticizing the history that occurs in society; (c) does not separate facts from existing values (Adian 2001).

The Critical Legal Studies movement is not always based on norms, but synchronizes legal theory and practice. Some people say that the Critical Legal Studies movement has a history but has no essence. Critical Legal Studies is often defined as an attitude of leftist dislike by academics towards the theory and practice of law that existed in the 1970s in the fields of: legal education, very strong political influence on the aspect of law, failure of the role of law in answering existing problems. (Azizy 2006).

The 1970's, CLS began to develop into exist, which was the result of a 1977 conference on Critical Legal Studies in the United States. while in England the Critical Legal Studies movement was formed in 1984. The Critical Legal Studies conference meeting in 1974 discussed the gap between law in theory (law in box) and law in action and the failure of law to respond to problems that occur in society (Blomley 2010)

The birth of the theory of Critical Legal Studies is the background of the theory to analyze the existence of doctrines of legal experts, legal education, and the practice of legal institutions that support a system of oppressive and not egalitarian relations. It is necessary to think radically in order to be critical of the state of political, economic and social relations that can encourage the creation of human emancipation (Fitzpztrick 2018).

The Principles of Critical Legal Studies in Social Sciences

The flow of Critical Legal Studies has several general characteristics as follows: 
1. This stream of Critical Legal Studies criticizes the prevailing law which in fact is in favor of politics, and is not at all neutral.

2. The theory of Critical Legal Studies criticizes law which is full and dominant with certain ideologies.

3. This theory of Critical Legal Studies has a strong commitment to individual freedom with certain limitations, because this theory is associated with the emancipation of humanity.

4. The teaching of Critical Legal Studies does not believe in abstract forms of truth and truly objective knowledge. Therefore, the teachings of Critical Legal Studies strongly reject the teachings of legal positivism

5. This theory of Critical Legal Studies rejects the difference between theory and practice, and also rejects the difference between facts and values, which is characteristic of liberalism.

In principle, the Critical Legal Studies school rejects the opinion of traditional legal experts who say: Law is objective, law is of course neutral. The critical law expert has a view: Law seeks wrong legitimacy, law is shackled by contradictions, There is no such thing as basic principles in law is not neutral. In other words, Critical Legal Studies is in an opposition position, so that this flow will never stop moving and continue to criticize the existing law, because if this flow is silent then this flow will again be trapped in legal positivism (Fuady 2016).

\section{The Constraints in Implementing the 2019 Simultaneous Election According to Sharia Faculty Student of IAIN Ponorogo}

Critical thinking is one of the prerequisites for a civilization to be able to reach a bright future. Critical thinking is not merely being cynical in responding to a phenomenon. More than that, critical thinking will provide stimulation and positive energy so that life can get better. One expert argues that critical thinking is the ability to think clearly and rationally. If a person thinks critically, the individual is able to understand the logical relationship of a thought, be able to identify, make and evaluate an argument, detect inconsistencies and errors in thinking, solve problems systematically, and be able to identify the relevance and importance of an idea.

There is a close relationship between constitutional law and administrative law, in carrying out governmental functions to gain authority. The government has legality in making laws and regulations that are eingriffverwaltung, including the nature of leistungs verwaltung, actions of eingriffverwaltung, certain circumstances can also be felt unfair by other parties, for example violating the principle of equality of treatment from general principles of administration having the right and obligation to receive protection guarantees (Judge 2011).

Law No. 15 of 2011 about Election Implementation explains that the General Election is defined as the implementation of people's sovereignty which is held directly, publicly, freely, secretly, honestly, and fairly in the Unitary State of the Republic of Indonesia based on Pancasila and the Republic of Indonesia Constitution 1945. To elect the President, Head of Regional, House of Representative (DPR), Regional House of Representative (DPRD). The election administration is carried out by the General Election Commission $(K P U)$ and the Election Supervisory Body (Bawaslu) as a single function. The duties of the $K P U$ as a national, permanent and independent Election Management institution are in charge of implementing the Election. Meanwhile, Bawaslu is the supervisory agency for the election process.

Institutionally, the current $K P U$ is the third KPU formed after democratic elections since the 1998 reform, the first KPU (1999-2001) was formed by Presidential Decree No. 16 of 1999 which contains 53 (fifty three) members who come from elements of the government 
and political parties and were appointed by President BJ Habibie. The second KPU (20012007) was formed by Presidential Decree No. 10 of 2001 which contained 11 members from academic and NGO elements, inaugurated by President Abdurrahman Wahid (Gus Dur) on April 11, 2001. The third KPU (2007-2012), formed based on Presidential Decree No. 101 / P / 2007. The implementation of an honest and fair election is an important factor for the election of representatives of the people who are of higher quality and are able to represent the aspirations of the people. As election organizer, the $K P U$ is required to be independent and impartial. Moral integrity as an election organizer is very important, in addition to being the driving force for the KPU, it also makes the KPU more credible in the eyes of the public because it is supported by honest and fair personalities. For this reason, on the suggestion of the DPR-RI initiative to formulate and together with the government, establish Law Number 22 Year 2007 concerning Election Administrators. Previously, the existence of election organizers was contained in Article 22-E of the Indonesia Constitution 1945 and Law Number 12 of 2003 concerning the Election of DPR, DPD and DPRD, Law Number 23 of 2003 concerning the Election of President and Vice President.

Law Number 22 of 2007 concerning Election Administrators (Election Administrators Law) is regulated regarding General Election organizers which are carried out by a General Election Commission (KPU) that is national, permanent, and independent. The national character reflects that the KPU's work area and responsibility as the organizer of the General Election covers the entire territory of the Unitary State of the Republic of Indonesia. The permanent nature shows the $K P U$ as an institution that carries out its duties on an ongoing basis even though it is limited by a certain term of office. The independent nature confirms that the KPU in holding General Elections is free from the influence of any party.

Election Administrators Law regulates KPU, Provincial KPU, and Regency / Municipal $K P U$ as permanent election administering bodies and Bawaslu as Election supervisory bodies. In carrying out its duties, the $K P U$ is responsible in accordance with the laws and regulations, as well as for the implementation of all stages of general elections and other duties. The KPU reports the President to the House of Representatives. According to Election Administrators Law, the composition of $K P U$ membership must take into account women's representation of at least $30 \%$ (thirty percent). The $K P U$ membership period is 5 (five) years from the time the oath / pledge is pronounced.

The method for selecting KPU member candidates according to Election Administrators Law is that the President forms a Selection Team for $K P U$ member candidates on May $25^{\text {th }} 2007$ consists of five people who help the President determine $K P U$ member candidates, which are then submitted to the House of Representatives to take the fit and proper test in accordance with the provisions of Article 13 paragraph (3) of Election Administrators Law (KPU 2021).

The current election implementation has a bicameral system with a variety of choices for political parties, which are held simultaneously in 34 provinces throughout Indonesia. where from the regency / city, province, to the capital city carry out presidential elections and legislative elections. The $K P U$ as election organizer facilitates voters to conduct elections in each village and sub-district, the implementation of the election is supervised by KPPS and Bawaslu officials. Both the KPU, Bawaslu, Panwaslu, and KPPS officials carry out elections in accordance with Law No. 15 Year 2011 concerning Election Implementation Article 1 point 5 states that the election organizer is an institution that is tasked with holding elections, namely the KPU and Bawaslu, as a unitary function to organize the elections for $D P R$, $D P R D, D P D$, President and Vice President, directly by the people, and elects Governors, Regents and Mayors.

Public Participation of Elections in Indonesia based on Article $22 \mathrm{E}$ of the 1945 Constitution states that: General elections are carried out in a fair manner to elect the $D P R$, 
$D P R D, D P D$, President and Vice President from each political party which is carried out by the $K P U$ as election organizer. The implementation of elections is the people's sovereignty to elect representatives for representatives in the executive and leaders in the executive.

People's representatives who are elected through elections with the aim of changing leadership in a peaceful government, the elected leaders must represent the interests of the people, fulfill the people's sovereignty and implement human rights. Based on the results of interviews with 100 students of the Sharia Faculty of IAIN Ponorogo, it can be obtained results related to the implementation of the election that (IAIN Ponorogo 2020 students)

1. $80 \%$ of students prefer the current election system, because it saves money by being held simultaneously with the legislative elections;

2. Regarding the vision and mission presented by the 2 presiden and vice presiden candidates: $60 \%$ understood why choosing the presiden candidate, $30 \%$ continued or elected the previous president and it was proven, $10 \%$ did not understand the vision and mission because the most important thing was to choose especially all the students who becoming a qioner for the first time giving the right to vote;

3. Criticism of organizers: $90 \%$ agreed that the KPU or Panwaslu be more effective in disseminating election implementation not only through social media, but direct directives especially for first-time voters;

4. Students' understanding of political parties: 40\% understand and know about political parties, $40 \%$ only know the political parties that believe in, $20 \%$ know what political parties are called but don't understand;

5. Regarding students' understanding of the rules regarding the Election: $60 \%$ know the rules but do not understand, $30 \%$ understand because they are law students, $10 \%$ do not know;

6. Regarding the problem of election violations: $42 \%$ of students stated that if the violations that occurred should have been immediately dealt with by the Bawaslu, and if the violations were serious the election should be canceled, 33\% clearly saw whether it was a violation or just a campaign strategy because it had to be put forward the presumption of innocence, $25 \%$ who will take action because we understand that law enforcement in Indonesia is weak, many reports from the public are also not immediately responded to, even they can still walk as a member of parliament;

7. Regarding the KPU in holding the current election: $52 \%$ of students are satisfied, $32 \%$ feel that the election administration is still lacking, in terms of the welfare of the committee and its officers, especially simultaneously, $16 \%$ is very poorly coordinated, with many officers and committees election in KPPS which was exhausted until died because of simultaneous elections;

8. The aim of giving voting rights: $60 \%$ as a form of love for the country and want the nation to be better and more advanced, free from corruption, $30 \%$ there needs to be a change for this country, $10 \%$ feel called to give voting rights that can determine the nation's future and this country;

9. Regarding the criticism, will it be conveyed to the parties concerned: $35 \%$ dared to convey, $30 \%$ was just a conversation with friends, $20 \%$ kept to themselves, $5 \%$ did not care;

The advantage of having simultaneous elections is that elections become practical, save time and are not long-winded. The simultaneous elections are very conducive, because the elections are held simultaneously. $K P U$ is the organizer of the election to accelerate the implementation of elections, this simultaneous election saves the cost of ballot papers. voters do not have to go back and forth to the voting place, and the cost of holding elections is definitely more efficient. The parties that will carry them out can prepare their candidates to 
run in elections simultaneously. The hope of the community that simultaneous elections will bring about better changes, use their voting rights simultaneously to elect the legislative body and the election of the president and vice president candidates.

Several students served as KPPS officers, students who carried out their duties were of the opinion that the simultaneous elections had many weaknesses, namely: lack of security or oversight of fraud, so that security from TNI Polri is needed. Lack of active officers, many do not know how to choose it takes a long time due to lack of socialization. So that in practice there are still many who do not know how to choose, it is very complicated to choose because the paper is too large. The large number of candidates makes most of the people less about these candidates. Thus causing voters to be confused in determining their choice.

Factors of Sharia Faculty Student IAIN Ponorogo Interested in Choosing Candidate Pair for President and Vice President No. 1 and Candidate Pair for President and Vice President No. 2

A nation needs people who can think critically, to be able to shape and create a national civilization that you aspire to, namely; prosperous, just and welfare. This began with independence starting on August $17^{\text {th }}, 1945$, at this time it was called the Old Order. After changing President Soekarno to President Soeharto into the New Order, the fall of the New Order with the fall of President Soeharto. The reform era began with the president BJ. Habibie, changing president from President Megawati Soekarno Putri, Susilo Bambang Yudhoyono, President Jokowi Widodo. The replacement of the president cannot be separated from the openness of political communication.

The election is not only in the election of the head of state, namely the president and vice president, to advance the region, it is necessary to select regional heads in every province in Indonesia. The guidelines for the development of digitalization changes from the past to the present, affect the general elections for the head and vice head of regional. So that the law undergoes changes, in the statutory rules legally according to the needs of the community. Election for the head / vice head of regional is selected through a mechanism in their respective regions, candidates who will advance are selected or appointed directly by political parties. Automatically appointed regional head candidates, political parties also appoint vice head of regional. This raises the problem of legitimacy in post-conflict local elections, where the deputy regional head is not the same as the regional head. If the regional head is permanently unable to attend or is involved in a legal case, the vice head of regional must still get approval from the DPRD to replace the previous regional head (Pardede 2018).

Power and authority in constitutional science, open communication is needed for the people. Power will not be achieved without political aspects including political parties, interest groups, political communication, pressure groups, and political figures. Prospective candidates for election need a political campaign to gain power and authority. This refers to constitutional science, social science and political science. Constitutional law contributes to building political democracy in a constitutional manner, communication science contributes to political communication ethics not violating laws and regulations. These three sciences have the aim of gaining electability in gaining people's sympathy (Sudrajat 2018).

According to Article 7 of the 1945 Constitution of the Republic of Indonesia, "The President and Vice President hold authority for five years, after which they can be re-elected to the same position, only for one term of authority." Thus, Joko Widodo, who holds the position of President of the Republic of Indonesia for the 2014-2019 period, has the right and can apply for re-nomination for the 2019 general election with a term of 2019-2024. President Joko Widodo has officially announced the vice president candidate who will accompany him in the 2019 general election, namely Professor KH Ma'ruf Amin on August 9, 2018 in Jakarta. Meanwhile, the other president candidates, namely Prabowo Subianto as President candidate and Vice President candidate Sandiga Uno. The government also raises a threshold for the 2019 election, so according to Effendi Ghazali, a political communication 
expert from the University of Indonesia, the government is considered to carry the interests of political parties. This can be seen in the following table (KPU 2020):

\begin{tabular}{|c|c|c|c|c|c|}
\hline Tipe & Package A & Package B & Package C & Package D & Package E \\
\hline Presidential threshold & $\begin{array}{c}20 \% \\
\text { (seat)/25\% } \\
\text { (vote) }\end{array}$ & $0 \%$ & $\begin{array}{c}10 \% \\
\text { (seat)/15\% } \\
\text { (vote) }\end{array}$ & $\begin{array}{c}10 \% \\
\text { (seat)/15\% } \\
\text { (vote) }\end{array}$ & $\begin{array}{c}20 \% \text { (seat) } / 25 \% \\
\text { (vote) }\end{array}$ \\
\hline $\begin{array}{l}\text { Parliamentary } \\
\text { threshold }\end{array}$ & $4 \%$ & $4 \%$ & $4 \%$ & $5 \%$ & $4 \%$ \\
\hline Electoral System & Open & Open & Open & Open & Open \\
\hline Seat & $3-10$ & $3-10$ & $3-10$ & $3-8$ & $3-10$ \\
\hline Vote Convertion & $\begin{array}{c}\text { Sainte- } \\
\text { Laguë Pure }\end{array}$ & Kuota Hare & Kuota Hare & $\begin{array}{c}\text { Sainte-Laguë } \\
\text { murni }\end{array}$ & Kuota Hare \\
\hline Result 1 & \multirow{2}{*}{$\begin{array}{c}\text { PDI-P, } \\
\text { Golkar, } \\
\text { Nasdem, } \\
\text { Hanura, } \\
\text { PKB, PPP }\end{array}$} & $\begin{array}{c}\text { Gerindra, } \\
\text { Demokrat, } \\
\text { PKS }\end{array}$ & PAN & - & - \\
\hline Result 2 & & - & & & \\
\hline
\end{tabular}

From the results of interviews and filling out the questionnaires of 100 Sharia Faculty students, the students' critical thoughts about the president candidates and their representatives who will be selected and the reasons are: We gathered 80 students to be interviewed by filling in the questionnaire that we distributed, from this it was seen in the president election:

1. It was found that 65 students chose candidate number 1, namely Joko Widodo and Ma'aruf Amin and 35 chose the president candidate and the vice president candidate number 2 namely Prabowo Subianto and Sandi.

2. From the current presidential election system with previous elections, $90 \%$ of respondents stated that they prefer the current system because it will run simultaneously with the legislative elections.

3. Towards presidential candidates: $95 \%$ of students said that the current presidential election was easier because there were only two candidates.

4. Regarding the presidential threshold election system: According to students $50 \%$ do not understand, $30 \%$ understand, and $20 \%$ do not understand. The most important reason is channeling the right to vote.

5. Reasons for electing a certain president: $80 \%$ already know the credibility of their work in the previous five years, $20 \%$ are attracted by their vision and mission so they need to change the president.

6. Factors that resulted in electing a certain President:

a. From number 1 (55 students): 70\% (of all student opinions who voted for number 1) increasing development factors, especially transportation infrastructure, $60 \%$ (of all student opinions) managed to eradicate corruption in the previous 5 years of government, an increase $40 \%$ community welfare, $80 \%$ he is populist and his representatives are big imam figures.

b. From the choice number 2 (25 students): $50 \%$ of his figure is firm and trustworthy, $30 \%$ interested in his vision and mission, $20 \%$ because from the 
military, Indonesia is still better off being led by a president than the military. The reason: can be more assertive, and state sovereignty can be maintained, resolving conflicts well.

7. Regarding the vision and mission conveyed by 2 president and vice president candidates: $60 \%$ understood why choosing the president candidate, $30 \%$ continued or elected the previous president and it has been proven, $10 \%$ did not understand the vision and mission because the most important thing was to choose especially all the students who becoming a qioner is giving the right to vote for the first time.

8. Regarding the lure of basic necessities, etc from candidate 1 and candidate 2: $43 \%$ are not affected, $34 \%$ do not like it, $13 \%$ like it, $10 \%$ really hope.

9. The aim of giving voting rights to candidate 1 and candidate $2: 60 \%$ is a form of love for the homeland and wants the nation to be better and more advanced, free from corruption, $30 \%$ there needs to be a change for this country, $10 \%$ feel called to give voting rights .

\section{Factors of Sharia Faculty Students IAIN Ponorogo in Choosing Legislative Candidates for the 2019 General Election}

The creation of clean, honest and fair election results requires the participation of various elements such as; The mass media are the people and the media as direct observers of the election. Guarding the election requires public and media participation in guarding the election, if election fraud occurs, the public and the media can report to Bawaslu, DKPP, and Constitutional Court. A quality election requires a monitoring process from public participation, from start to finish, namely the determination of election results. The monitoring of the 1999 elections for the New Order regime was aimed against power. Furthermore, election monitoring developed, after the 1999 election to the 2014 election, providing input on election results, voter data, election rules, election administration, and publishing election results. election monitoring recedes along with the presence of volunteer election observers to help with funding, election technology innovation, election knowledge, transparency of election results (Simanjuntak 2017).

The first regional election (Pilkada) was directly started in 2005, not only the postconflict local elections had problems. However, the legislative and presidential elections also have many problems, which must be resolved in order to find a way out. Political education to the public to justify the public's opinion that there is no money politics to elect certain political parties and candidates in the election. Other reforms are the cadres of political parties who have the integrity and capability to manage their regions, the relegation of election organizers to impose election administration sanctions. Namely the cancellation of candidates and disqualification proven to be a violation of other business money politics, reducing campaign costs, facilities and infrastructure for elections are fulfilled by each KPUD (Jamaludin 2018)

Political parties are indispensable as a vehicle for advancing in elections, candidates who will advance cannot be separated from the role of political parties. It is very difficult for someone to advance to become a legislative candidate through independent way without the support of a political party, especially if the candidate is not known by the public. With the existence of a political party the objectives are; carrying out the programs and ideology of the party, conveying aspirations to the community and parties, having a political attitude towards the problems of the nation, attracting members and activating members through political parties, participating in government policies through political parties.

However, political parties also have weaknesses, namely; cadres are elected by people who are known to the public regardless of their abilities, cadres who come from officials representing the interests of the party and not the interests of the people, regional leaders and legislators all of their implementation and activities must obtain party approval. 
The general election used by countries in the world consists of three systems, namely; majority which dominates from others, a plurality system which is willing to accept proposals from various parties, and a proportional system where there is an even distribution between the supporting parties and the opposition parties. In addition, elections are divided into several principles. The general principle is implemented nationally to elect people's representatives in the regions. The periodic principle is that elections are held within a certain period of time. The principle of honesty means that an election cannot only give promises, these promises must be carried out. Principles of equality and justice. The principle of free, direct, secret is to choose directly, free to make choices without being noticed by others.

Finding out the critical attitude of students towards political parties in the legislature, it will be classified as follows:

1. Student's understanding of political parties: $40 \%$ understand and know political parties, $40 \%$ only know the political parties that believe in, $20 \%$ know the term political parties but don't understand.

2. Understanding of political party and non-political party legislative candidates: $60 \%$ know, $40 \%$ don't know

3. Reasons for choosing a candidate: $40 \%$ because they know, $30 \%$ know the vision and mission, $20 \%$ have been tested, $10 \%$ are important to vote

4. Are affected by their vision and mission: $50 \%$ are affected, $30 \%$ at least the same, $20 \%$ are not affected by the vision and mission, which is important what has been done and proven during the candidacy (providing basic needs, etc.).

5. Understand the threshold for selecting legislative candidates: 50\% clear, $40 \%$ less understand, $10 \%$ do not understand

6. Regarding the alignments and interests of candidates: $50 \%$ think they definitely prioritize their political parties over the welfare of the people, $30 \%$ whatever the important way is to get elected, $20 \%$ think when elections are very close to the people, after being elected they often forget

7. Regarding the elected candidates: $45 \%$ believe that the elected candidates are appropriate, $30 \%$ because of the elected candidate figures, $15 \%$ of the candidates are interesting from their vision and mission, $10 \%$ listen to other people's opinions.

8. Regarding the lure of basic foodstuffs, of the candidates participating in the 2019 elections at this time: $43 \%$ are not affected, $34 \%$ don't like it, $13 \%$, like it, $10 \%$ are very hopeful.

9. The aim of giving the right to vote for both candidates is $D P R D$ Province, $D P R D$ Regional, DPR and DPD: $60 \%$ as a form of love for the country and want the nation to be better and more advanced, free from corruption, $30 \%$ there needs to be a change for this country, $10 \%$ feel called to give voting rights.

The House of Representative's legislative elections, district / city's DPRD, Provincial's $D P R D$, and presidential elections being elected simultaneously or at the same time greatly confuse voters and inconvenience KPPS officers. The election committee in charge of causing disrespect for the committee, the KPPS which has to work a full 24 hours even until someone dies, should be separated between the candidates and the president or the KPPS pay is added. The level of difficulty in voting was because there were 5 (five) ballots punched while the socialization was lacking. The technical vote counting would also take a long time to collect data and votes. Many people are too fanatical, the two camps do not tolerate it, and one of the losers who causes a chaos that takes its victim.

The creation of clean, honest and fair election results requires the participation of various elements such as; The eyes of the masses are the public and the media as direct observers of the election. Election guard requires public and media participation in guarding the election, if election fraud occurs, the public and the media can report to Bawaslu, DKPP, 
or Constitutional Court. A quality election requires a monitoring process from public participation, from start to finish, namely the determination of election results. The monitoring of the 1999 elections for the New Order regime was aimed against power. Furthermore, election monitoring developed, after the 1999 election to the 2014 election, providing input on election results, voter data, election rules, election administration, and publishing election results. election monitoring recedes along with the presence of volunteer election observers to help with funding, election technology innovation, election knowledge, transparency of election results (simanjutak 2017).

\section{CONCLUSION}

Students of Sharia Faculty IAIN Ponorogo have obstacles in the implementation of the 2019 election including; lack of understanding because the $K P U$ is still lacking in disseminating the implementation of elections, unknown legislative candidates, election violations, and many KPPS officers have died. Factors for students from the Sharia Faculty of IAIN Ponorogo to elect pairs of candidates for President and Vice-president are those who will be chosen, in terms of the vision and mission that has been conveyed, in terms of the success that has been shown, the factors of the president and vice-president candidates are also their considerations in giving voting rights, choosing a candidate because follow parents. And student factors of the Sharia Faculty IAIN Ponorogo choose legislative candidates from if they know the legislative candidates choosing from the vision and mission of the legislative candidates, but if the legislative candidates are not known to choose from political parties, they choose because they get basic food and money.

The Suggestion of this research: First, KPU must provide election socialization to the public, Bawaslu should take firm action against the implementation of the election, before the election, KPPS officers should have their health checked so that they are healthy and no one dies. Second, Sharia Faulty of IAIN Ponorogo's students should get to know more about the pairs of candidates for President and Vice President by understanding the vision and mission of the pairs of candidates for President and Vice President who will register. Sharia Faulty of IAIN Ponorogo's students should better understand the vision and mission of legislative candidates and for students who vote because there are legislative candidates / parties that provide basic necessities, they refuse and immediately report election violations to Bawaslu.

\section{Acknowledgments}

I say thank to God, my family, and all friends who support us to finish this research.

\section{References}

\section{Books}

Adian, Donny Gahral Arus Pemikiran Kontemporer.Jalasutra. Yogyakarta: , 2001

Azizy, Qodry Menggagas Hukum Progresif Indonesia. Pustaka Pelajar, Yogyakarta. 2006.

Blomley, Nicholas K. Law, Space, and the Geographies of Power. The Guilford Press. New York. 2010

Budiardjo, Mariam Dasar-dasar Ilmu Politik: P.T. Gramedia Pustaka Utama, Jakarta 2003

Fitzpztrick, Peter Sejarah Gerakan Critical Legal Studies. Gramedia Pustaka Utama, Jakarta . 2018

Fuady, Munir Aliran Hukum Kritis. Jakarta : P.T. Gramedia Pustaka Utama, Jakarta 2016

Gahral Adian, Donny Arus Pemikiran Kontemporer . JalasutraYogyakarta, 2001. 
Postner, Richard A.Frontier Legal Theorie. Harvard University Press, Inggris. 2001

Rottleuthner, Hubert Sumbangan Teori Kritik dari Madzhab Frankfurt Terhadap Perkembangan Sosiologi Hukum," Dalam Sociological Approaches to law, Podgorecti, Salman, Otje dan Susanto, Anthon F.Teori Hukum, Refika Aditama,Bandung 2004

Sumekto FX. Adji. Studi Hukum Kritis ; Kritik Terhadap Hukum Modern. Jakarta. Pustaka Ilmu.Jakarta 2013.

Wignjosoebroto, Soetandyo Doktrin Supermasi Hukum: Sebuah Tinjauan Kritis dari Perspektif Historik," dalam buku Wajah Hukum di Era Reformasi .Kumpulan karya Ilmiah Menyambut 70 Th. Prof. Satjipto Rahardjo. Citra Aditya Bhakti, Bandung.2010

\section{Journals}

Danardono, Donny. Critical Legal Studies: Posisi Teori Dan Kritik . Jurnal Ilmiah Hukum Kisi Hukum. Vol.1 No.1. 2019.

Hakim, Lukman. Kewenangan Organ Negara Dalam Penyelenggaraan Pemerintahan. Puskasi FH Universitas Widyagama Malang. Jurnal Konstitusi, Vol. IV, No.1, Juni 2011

Jamaludin, Teten Kesuksesan Dan Problematika Pemilihan Kepala Daerah Secara Langsung Di Indonesia The Success And The Problematics Of Direct Regional Head Election In Indonesia . Jurnal Etik Dan Pemilu Vol 4 No 1 Juni 2018

Pardede, Marulak Legitimasi Pemilihan Kepala/Wakil Kepala Daerah Dalam Sistem Pemerintahan Otonomi Daerah Legitimacy of Regional Head/Deputy Head Election in The Regional Autonomous Administration System. Jurnal Penelitian Hukum De Jure, Issn1410-5632 Vol. 18 No. 2, Juni 2018.

Simanjuntak, Novembri, Yusuf Pemantauan Dalam Proses Penyelenggaraan Pemilu Magister Ilmu Politik Konsentrasi Tata Kelola Pemilu Universitas Airlangga, Jurnal Bawaslu Issn 2443-2539 Vol.3 No. 32017

Sudrajat, Hendra. Hubungan Komunikasi Politik Dengan Hukum Tata Negara Dalam Kampanye Pemilihan Umum . MCC Conference Proceeding, Jurnal Conference on Dynamic Media, Communications, and Culture . Vol. 1, 2018

Widyo, Gandha. Integritas Pemilu Proses Verifikasi Peserta Pemilu di KPUD Pada Pemilu Legislatif 2014 . Jurnal Politik Indonesia” Vol. 2, No. 1, Juli-September 2017

Regulation

Undang-Undang Nomor 22 Tahun 2007 Tentang Penyelenggara Pemilu

Internet

www.kpu.go.id 